\title{
Malignant Testicular Germ Cell Tumor
}

National Cancer Institute

\section{Source}

National Cancer Institute. Malignant Testicular Germ Cell Tumor. NCI Thesaurus. Code C9063.

A malignant tumor predominantly affecting young men and often associated with cryptorchidism. Seminoma is the most frequently seen malignant testicular germ cell tumor, followed by embryonal carcinoma and yolk sac tumor. 